\title{
GROWTH TREND OF DEPOSIT INSURANCE FUND AND RISK- ASSET INDICATORS OF DEPOSIT MONEY BANKS IN NIGERIA: A TIME SERIES ANALYSIS
}

\author{
Joel Adeniyi OKEWALE
}

Department of Accounting, Faculty of Management Sciences, Olabisi Onabanjo University, Ago-Iwoye, Nigeria

\section{Kenny Adedapo SOYEMI}

Department of Accounting, Faculty of Management Sciences, Olabisi Onabanjo University, Ago-Iwoye, Nigeria

\section{Ebipanipre Gabriel MIESEIGHA}

Department of Accounting, Faculty of Management Sciences, Olabisi Onabanjo University, Ago-Iwoye, Nigeria

Received 19. April 2020, Reviewed 05. June 2020, Accepted 30. June 2020

\begin{abstract}
The growth trend of deposit insurance fund and selected risk-asset indicators of Nigerian banks was investigated using two disaggregated models. The ex-post facto design was and annual time series data obtained from the Nigerian Deposit Insurance Corporation annual reports and accounts during the period 1987-2017 was employed. Data of deposit insurance fund, total deposits of insured banks, target reserve ratio of total insured deposits, total loans and advances and asset quality. The autoregressive distributed lag estimation technique was employed to estimate the link between deposit insurance fund on the volume of loans and advances and other target reserve ratio and asset quality. Findings indicated that volume of total loans and advances were negatively and statistically significant to deposit insurance funds. It was recommended that the Nigerian banking sector should form a partnership with deposit money banks in order to diversify and efficiently minimise incidences of fraud
\end{abstract}

Key words: Asset quality, deposit insurance fund, loans and advances, risk-assets, Nigerian Deposit Insurance Corporation

JEL Classification: E5, M2, M4 


\section{Introduction}

The Nigerian banking sector is one of the most regulated and deregulated sectors of the economy. Fundamental among the regulatory agencies of the Nigerian banking sector are the Central Bank of Nigeria(CBN) and Nigeria Deposit Insurance commission(NDIC). While the CBN supervises and controls banking activities, NDIC initiates, supervises and controls deposit insurance scheme among Nigerian financial institutions. Basically, deposit insurance scheme refers to a mutual insurance system fully funded by insured deposit money banks (commercial banks) and administered either via privately held agencies or a government-controlled agency. These agencies according to Nwokoji (2011) warranty deposits of insured institutions and being able to speedily reimburse depositors in event of an ailed insured bank. Consequently, deposit insurance scheme grew due to the need to provide some forms of protections to depositors who may stand chances of losing their funds in event of bank failure.

In Nigeria, the deposit insurance scheme was initiated in 1988 and administered by the NDIC as a financial safety net to moderate systemic crises. In the views of the World bank Group (2016), Alford (2012); Cheng and Ellyne (2011); Mbarek and Dorra (2011), a well-designed deposit insurance scheme should possess adequate tools to ensure the availability of funds needed to speedily reimburse depositors of insured banks and equally meet operating expenses. According to the NDIC (2016), deposit insurance fund has grown over the years but this growth has not significantly curtailed the tides of troubled and failed bank. This insignificant growth compelled the regulatory framework of banks to initiate consolidation of banks in 2005; and setting up of Assets Management Company of Nigeria (AMCON), a versatile medium to buy up toxic assets of troubled Nigerian banks (Obienusi \& Obienusi, 2015).

In view of these developments by the regulatory frameworks of banks, the NDIC came under ceaseless pressure to deliver on its basic mandate of ensuring financial system stability (Ani \& Ogar, 2018); however, there are robust debates among researchers and stakeholders of banks as to the effectiveness of the NDIC in discharging this arduous obligation. Moreover, in accounting literature, there are vast empirical studies on risk/fraud management and bank sustainability and performance in Nigeria, the world over. It is worrisome to note that there is dearth of empirical study on growth trends of deposit insurance fund and selected risk-asset indicators of banks in both developed and developing countries. Therefore, this study was carried out with the view to assessing the growth trends of deposit insurance funds and some selected risk-asset indicators of Nigerian banks.

\section{Deposit Insurance Fund}

The concept of deposit insurance fund refers to accumulated funds built over the years by the deposit insurers as a result of premium collection from insured financial institutions. Predominantly, the fund is used for resolving the challenge of ailing financial institutions and for prompt reimbursement of depositors' claims when banks are declared ailed. Moreover, the deposit insurance funds are needed in order to safeguard the assets or deposits of depositors in the event of liquidation of commercial, micro-finance/mortgage and non-interest banks. Thus, at the point of liquidation, these funds are made available to pay depositors in a preference that will be devised by the regulatory framework of the funds.

In the context of Nigeria, the Nigerian Deposit Insurance Commission (NDIC) is responsible for this sole act. The NDIC maintains three (3) of the insurance 
funds namely, deposit insurance, special insured institutions and non-interest deposit insurance funds for commercial, micro-finance/ mortgage and non-interest banks. The sources of financial resource for the deposit insurance fund could either be private or public. In view of global best practice, IADI (2014) stipulates that the most suitable means to determine the adequacy of any given deposit insurance fund is the target fund ratio or perhaps the reserve ratio.

Furthermore, the IADI (2014) reiterated that adequate funding is germane to the smooth running and implementation of a deposit insurance scheme in order to enable these banks (commercial, micro-finance/ mortgage and non-interest banks) meet their financial obligations as and when they fall due. Consequently, sufficient funding for deposit insurance scheme has severe implications for the credibility and confidence it elicits from stakeholders.

\section{Growth Trend of Deposit Insurance Fund}

Over the years, there has been dwindling movement or trend in deposit insurance fund, given the failure of 26 banks whose insured depositors were rereimbursed by the NDIC. Ensuing this period, deposit insurance fund grew steadily from N12.3 billion in 1999 to N57.5 billion in 2004; with a $21.4 \%$ increase in this period. However, in 2005, the deposit insurance fund witnessed a decline due to the reimbursement of claims of depositors of Peak Merchant and Savannah Bank. Moreover, recent statistics from the NDIC reveals that deposit insurance fund augment from $\$ 12.626 .96$ billion in 2014 to $\$ 16.24$ and $\$ 15.91$ trillion in 2016 and 2017 respectively.

Consequent upon this, the deposit insurance fund or the NDIC has experienced an unsteady growth trend in the past and in recent times. Furthermore, figure 1 captures the growth trends of the deposit insurance fund in Nigeria, particularly during the period 2014-2017. In fig. 1, it can be seen that the fund experienced more growth in recent years (2017) with a decline in prior periods of 2014-2016.

Fig. 1: Growth Trends of Deposit Insurance Fund

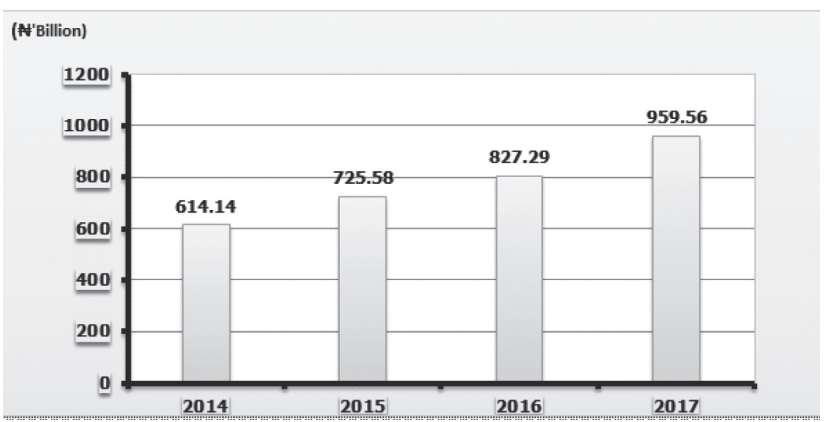

Source: Nigerian Deposit Insurance Commission (NDIC) Annual Report (2017). 


\section{Theoretical Framework}

This paper is premised on the stakeholders' theory propounded by Edward R. Freeman (1999). The theory outlines how management can satisfy the interest of stakeholders in order to make it sustainable. Stakeholder refers to any individual or group that have the capacity to influence the attainments of the organization's goals and objectives. Stakeholders entail shareholders (owners of wealth), management, employees, customers, government and regulatory agencies of financial institutions and passive stakeholders. Passive stakeholders encompassed the business environment and impending groups who need other bodies to act on their behalf. According to Freeman, an entity that wants to attained sustainable growth trend cannot exist in a vacuum, hence it requires that there individuals who can help enhanced the level of sustainable growth trend of the business. The more powerful stakeholders are, the more organization must adapt to their interests and demands.

The rudimentary proposition of theory of stakeholder is that an entity's success is reliant upon profitable management of all relationships that an entity has with stakeholders. The purpose of stakeholder's theory is to assist management and other regulatory agencies of banks understand their stakeholder and to manage more effectively within their corporate environment. This study is anchored on stakeholder theory because it contributes to how stakeholders (bank management and regulatory agencies of bank - Central Bank of Nigeria and Nigerian Deposit Insurance Commission) can effectively and efficiently manage the growth trend of deposit insurance funds and risk assets of banks.

\section{Empirical Review}

In accounting literature, there are vast empirical studies on risk management, fraud risk management and bank sustainability and performance of banks in Nigeria, the world over. However, there is dearth of empirical evidence on the growth trend of deposit insurance fund and selected risk-asset indicators of banks in both developed and developing countries. For instance, Chernykh and Cole (2011) studied eight hundred (800) banking institutions in Russia and found marked decline in bank assets quality arising from the implementation of a deposit insurance scheme. In addition, increases in loans to total assets ratio coupled with a parallel decrease in equity to total assets ratio was observed for deposit insurance institutions in Russia.

Muhammed, Shahid, Munir and Ahad (2012) employed descriptive (correlation) and inferential (regression) statistical techniques to investigate the effect of credit risk on bank performance in Nigeria during the period 2004-2008. Findings indicated that credit risk has significant effect on performance. Similarly, Kolapo, Ayeni and Ojo (2012) assessed the impact of credit risk on bank performance by means of panel data regression during the period 2000-2010. Bank performance was proxied by return on asset and findings showed that credit risk has a cross-sectional invariant effect on bank performance.

Onaolapo (2012) analysed the nexus between credit risk management efficiency and bank performance in Nigeria from 2004-2009. Findings revealed that a minimal causality between credit risk management efficiency (deposit exposure) and the performance of bank. In Malaysia, Aziz, Manab and Othman (2016) explored the link between sustainability risk management and financial performance using trend analysis. The study found that sustainability risk management does not only significantly affect financial performance but has a significant effect on the long-term survival of banks. 
In Romania, Meriala (2017) assessed risk management and sustainable development of banks by means of descriptive analysis and findings indicated that risk management contributes to the level of sustainable development among Romanian banks.

In Canada, Jesko and Sophie (2017) explored the challenges for integrating risk management in the Canadian banking industry. The descriptive statistics result revealed that the integration of risk management into the Canadian banking industry has improved the level of bank performance.

Similarly, by means of framework for strategic sustainable development, Jesko and Sophie (2018) examined company risk management and sustainability of bank and findings revealed that promising ways for maneuvering in a smart zone between being too passive and being too pro-active in relation to sustainable innovation is via risk management. Thus, company risk management significantly affects bank sustainability in Canada.

\section{Material and Methods}

In this paper, we adopted the ex-post facto research design by employing annual time series data obtained from the Nigerian Deposit Insurance Corporation (NDIC) annual reports and accounts during the period 1987-2017. Data of the study comprised of the aggregate deposit insurance fund, total deposits of insured banks, target reserve ratio of total insured deposits, aggregate loans and advances and asset quality for the period under investigation.

Given the nature of the empirical data, two empirical models were estimated: deposit insurance fund (dependent variable), total deposits of insured banks and loans and advances (independent variables) in model 1 and target reserve ratio of total insured deposits (dependent variable) and asset quality (independent variable) in model 2. The study model is estimated as:

$D I F B=f(T I D F, T L A D)$

Model $1 a$

DIFBt $=a_{0}+a_{1}$ TIDF $+a_{2}$ TLAD $+\mu_{t}$

Model $1 b$

Where: DIFBt $=$ Deposit insurance fund of banks in year $t$; TIDFt $=$ Total insured deposit of banks in year $\mathrm{t}$; TLADt $=$ Total loans and advances of bans in year $\mathrm{t}$; and $\mu=$ Error term.

$T R R B=f(A S Q T)$

Model $2 a$

$T R R B t=a_{0}+a_{1} A S Q T+\mu_{t}$ Model $2 b$

Where: TRRBt=Target reserve ratio of bank in year $\mathrm{t}$; ASQTt=Assets quality of bank in year t. Given the estimated model, the Autoregressive Distributed Lag (ADL) estimation tool alongside other inferential statistics like t-test, f-test, R-squared were utilized to assess the growth trend of deposit insurance fund and risk-asset indicators of Nigerian banks during the period under investigation. 


\section{Results and Debate}

Table 1: Summary of Descriptive Statistics

\begin{tabular}{|l|c|c|c|c|c|c|c|}
\hline \multicolumn{7}{|c|}{ Time Series Data: 1987-2017 } \\
\hline & Obs. & Mean & Std. Dev. & Min. & Max. & Kurt & Skw. \\
\hline $\begin{array}{l}\text { Deposit insurance fund } \\
\text { (DIFB) }\end{array}$ & 31 & 22002.71 & 40835.25 & 29.77 & 175629.6 & 8.61 & 2.46 \\
\hline $\begin{array}{l}\text { Total insurance deposits } \\
\text { (TIDF) }\end{array}$ & 31 & 922138.3 & 1869980.0 & 9.99 & 8702996.0 & 11.56 & 2.92 \\
\hline $\begin{array}{l}\text { Target reserve ratio } \\
\text { (TRRB) }\end{array}$ & 31 & 11.49645 & 15.49741 & 0.12 & 49.48 & 2.93 & 1.22 \\
\hline $\begin{array}{l}\text { Total loans and advances } \\
\text { (TLAD) }\end{array}$ & 29 & 3136.685 & 4212.824 & 15.91 & 13328.77 & 2.94 & 1.15 \\
\hline Asset quality (ASQT) & 29 & 21.77828 & 13.86069 & 2.81 & 45.5 & 1.83 & 0.26 \\
\hline
\end{tabular}

Source: Researcher's Computation via STATA 13.0

Presented in Table 1 are summary of descriptive statistics of deposit insurance funds and some selected risk-asset indicators of Nigerian banks during 1987-2017. Given the above statistics, it was found that deposit insurance funds and asset quality of banks have witnessed succession of unstable trends in the period investigated. First, the means for deposit insurance fund (22002.71), total insurance deposits (186998) and total loans and advances (4212.824) are clear indications that deposit insurance funds increased due to improvement in loans and advances as well as deposit insurance deposits with the NDIC. This implies that on the average, the trend in deposit insurance fund has been on moderate performance overtime.

In addition, the means for target reserve ratio (11.49645) and asset quality (21.77828) clearly indicated that for the period investigated, expansionary monetary policy has led to increase in loans, thus boosting economic activities in view of the fact that target reserve ratio is considered a low percentage. These results are further supported by their respective standard deviation values. Moreover, the kurtosis $\operatorname{DIFB}(0.8 .61), \operatorname{TRBB}(2.93), \operatorname{TLAD}(2.94)$ and ASQT(1.83) are platykurtic except TIDF(11.56) that is leptokurtic; an indication that the variables satisfies the normality condition.

Table 2: Results of Bound Tests

\begin{tabular}{|l|l|l|l|}
\hline \multicolumn{4}{|l|}{ Period: 1987-2017 } \\
\hline Model(s) & Variables Interaction & F-Statistics & Decision \\
\hline Model 1a & FDIFB (FDIFB/TIDF, TLAD) & $16.616^{* *}$ & Co-integration \\
\hline Model 1b & FTIDF (FTIDF/DIFB, TLAD) & $16.156^{* *}$ & Co-integration \\
\hline Model 1c & FTLAD (FTLAD/DIFB, TIDF) & $9.370^{* *}$ & Co-integration \\
\hline Model 2a & FTRRB(FTRRB/ASQT) & 0.114 & No Co-integration \\
\hline Model 2b & FASQT(FASQT/TRRB) & $3.804^{* * *}$ & Co-integration \\
\hline
\end{tabular}

Source: Researcher's Computation via STATA 13.0

(*significant@1\%,**significant@5\%, ***significant@10\%) 
Presented in Table 2 are the results of ARDL bound tests for co-integration of selected study variables (deposit insurance fund, total deposits of insured banks, loans and advances, target reserve ratio of total insured deposits and asset quality). In view of the results of ARDL bound tests, calculated F-ratio FDIFB(FDIFB/TIDF, $\mathrm{TLAD})=16.616$ is greater than the upper and lower bound critical value of 4.01 and 2.86 at the 5 percent significant level respectively.

This supports the assertion that there exists a long-run relationship cointegration between the variables of interest. Moreover, in relation to model 2 which shows the link between target reserve ratio and asset quality, calculated F-ratio FTRRB(FTRRB $/$ ASQT) $=0.114$ is lower than the upper and lower bound critical values, suggesting that only a short-run relationship exists between target reserve ratio and asset quality.

Table 3: Short-run ARDL Results

\begin{tabular}{|c|c|c|c|c|c|}
\hline \multicolumn{2}{|c|}{ Period: 1987-2017 } & \multicolumn{4}{|c|}{ Dependent Variable: DIFB) } \\
\hline & Variable & Coefficient & Std. Error & t-Statistics & Probability \\
\hline \multirow{9}{*}{ Model 1} & $\operatorname{DIFB}(-1)$ & 1.6097 & 0.044 & $39.923^{* *}$ & 0.000 \\
\hline & TIDB & -0.527 & 0.023 & $-24.797^{* *}$ & 0.000 \\
\hline & TLAD & -0.027 & 0.012 & $-2.392^{* *}$ & 0.043 \\
\hline & $\operatorname{TLAD}(-1)$ & -0.030 & 0.012 & $-2.597^{\star *}$ & 0.028 \\
\hline & R-Squared & 0.977 & & & \\
\hline & Adj. R-Squared & 0.975 & & & \\
\hline & D.W stat. & 1.538 & & & \\
\hline & \multicolumn{5}{|c|}{ Dependent Variable (TRRB) } \\
\hline & Variable & Coefficient & Std. Error & t-Statistics & Probability \\
\hline \multirow{7}{*}{ Model 2} & TRRB(-1) & 1.051 & 0.099 & $11.552^{* *}$ & 0.000 \\
\hline & ASQT & 0.609 & 0.185 & $3.596^{* *}$ & 0.003 \\
\hline & ASQT(-1) & -0.641 & 0.170 & $-4.124^{\star *}$ & 0.000 \\
\hline & C & 0.322 & 0.544 & 0.648 & 0.611 \\
\hline & R-Squared & 0.904 & & & \\
\hline & Adj. R-Squared & 0.893 & & & \\
\hline & D.W stat. & 1.652 & & & \\
\hline
\end{tabular}

Source: Researcher's Computation via STATA 13.0

(*significant@1\%,**significant@5\%,***significant@10\%)

Presented in Table 3 are the short-run ARDL result for models 1 and 2. In model 1, the lag value of deposit insurance fund (DIFB) shows a positive and significant association on itself; this suggests that $1 \%$ variation in DIFB in prior period will result to an increase in itself in current period. Besides, total loans and advances (TLAD) show a negative and significant association to deposit insurance fund (DIFB). This is a clear indication that an increase in the disbursement of loans and advances by commercial banks will result to a decrease in the share of DIFB by $(0.027 \%)$. Similar effect is captured in the lag coefficient value of TLAD, as its effect is inversely linked 
to DIFB. Also, the R-squared is 0.97 , signifying that the model is well fitted and that $987 \%$ of the variation in the dependent variable (DIFB) is explained by changes in the explanatory variables (TIDB and TLAD). However, the variation was suitably adjusted by variation in adjusted R-squared of $97 \%$ while the Durbin-Watson (DW) statistic is 1.538 , which is less than the rule of thumb value of 2 .

Furthermore in model 2, the lag value of target reserve ratio (TRRB) of commercial banks displays a positive and significant association to its self in current period, indicating that $1 \%$ change in prior period of TRRB will spur positive the current performance of TRRB. Also, asset quality (ASQT) shows a positive and significant effect of TRRB with coefficient value of 0.609 . This clearly indicates that $1 \%$ change in ASQT will spur an upward growth trend in TRRB. Also, the R-squared is 0.904 , implying that the model is well fitted. Precisely, the R-squared indicates that $90 \%$ of the variation in the dependent variable (TRRB) is explained by changes in the explanatory variable (ASQT). The DW statistic is 1.652; an indication that which is approximately equal to the rule of thumb value of 2 , which is less than the rule of thumb value of 2 . Hence, there is the absence of serial correlation in the model.

Table 4: Results of Breakpoint Tests

\begin{tabular}{|c|c|c|c|}
\hline \multicolumn{4}{|c|}{ Model 1: Chow Breakpoint Period: 2005} \\
\hline F-Statistics & 3.659 & Prob. $F(3,24)$ & 0.025 \\
\hline Log Likelihood ratio & 11.489 & Prob. Chi-Square(3) & 0.015 \\
\hline Wald Statistic & 10.979 & Prob. Chi-Square(3) & 0.019 \\
\hline \multicolumn{4}{|c|}{ Model 2: Chow Breakpoint Period: 2005} \\
\hline F-Statistics & 4.083 & Prob. $F(2,26)$ & 0.042 \\
\hline Log Likelihood ratio & 8.290 & Prob. Chi-Square(2) & 0.024 \\
\hline Wald Statistic & 8.167 & Prob. Chi-Square(2) & 0.026 \\
\hline
\end{tabular}

Source: Researcher's Computation via STATA 13.0

Presented in Table 4 are the results of breakpoint tests for models 1 and 2 . From the result, the structural breaks (2005) are fragmented into two periods: preconsolidation(1988-2004) and post consolidation(2005-2017) eras. The results showed that there was a significant policy drift between pre and post consolidation eras as given in the probability values (0.025), and (0.042) in models 1 and 2 respectively, which are less than $5 \%$ significant level. This is a clear indication that after liberalization era (consolidation), there was a significant policy drift for Nigerian banks. Perhaps, the policy drift emanate due to the policy reform of banks which commenced in 2005, hence strengthened the Nigerian financial system.

\section{Conclusion}

In this paper, we investigated the growth trend of deposit insurance fund and selected risk-asset indicators of Nigerian banks from 1988-2017. The Autoregressive Distributed Lag estimation technique was employed to estimate the association between deposit insurance fund on the volume of loans and advances and other target reserve ratio and asset quality. Data of the study were obtained from the Nigerian Deposit Insurance Commission (NDIC) findings indicated that volume of total loans 
and advances were negatively and statistically significant to deposit insurance funds. In addition, it was discovered that asset quality in the current period is statistically positive to target reserve ratio of Nigerian banks.

In view of the study findings, it was recommended that the regulatory frameworks of the Nigerian banking sector should form a partnership with deposit money banks in order to diversify and effectively and efficiently manage other mechanisms of risk such as minimising incidences fraud rather than over concentrating on credit risk management which unvaryingly incline banks to other risks. As a matter of fact, this can be attained by initiating collaborative strategies aimed at intensifying the implementation of prevailing measures needed to combat fraud in the Nigerian banking sector.

\section{Bibliography}

1. Alfred, D.E. (2012). Reform of the Nigerian banking system: Assessment of the asset management corporation of nigeria (AMCON) and recent developments (February 2012) Social Science Research Network Working Paper.

2. Ani. U.W \& Ogar .A.(2018). Effect of deposit insurance fund on the safety of bank deposit in Nigeria IIARD International Journal of Banking and Finance Research, $4(2), 65-72$

3. Aziz, N.A., Manab, N.A. \& Othman, S.N. (2016). Sustainability risk management (SRM): An extension of enterprise risk management (ERM) concept. International Journal of Management and Sustainability, 5(1), 1-10

4. Cheng, R. \& Ellyne, M. (2011). Valuation of deposit insurance in South Africa using an option-based model. A paper presented at the Biennial Conference of the Economic Society of South Africa, 5-7 September 2011, University of Stellenbosch, South Africa

5. Chernykh, L. \& Cole, R.A (2011). Does deposit insurance improve financial intermediation? Evidence from the Russian experiment. Journal of Banking and Finance, 388-440

6. Jesko, S. \& Sophie, H. (2017). Challenges for integrating sustainability in risk management: Current state of research. 21st International Conference on Engineering Design, 21-25 August, 2017, The University of British Columbia, Vancouver, Canada

7. Jesko, S. \& Sophie, H. (2018). Company risk management in light of the sustainability transition. Journal of Sustainability, 10(4), 2-25

8. Kolapo, T. F., Ayeni, R. K. \& Oke, M. O. (2012) Credit risk and commercial bank's performance in Nigeria: A panel model approach. Australian Journal of Business and Management Research, 2(2), 1-10

9. Mbarek, L. \& Dorra, D.M (2011). Deposit insurance and bank risk-shifting incentives: Evidence from the Tunisian banking system. Journal of Money, Investment and Banking, 20(2011), 1-12

10. Meriala, G. (2017). Risk management in the context of sustainable development. Scientific Papers of Bucharest, 1(1), 1248-1254

11. Muhammed, T., Shahid, O., Munir, Y. \& Ahad, A. (2012) Credit risk and the performance of Nigerian banks. Interdisciplinary Journal of Contemporary Research in Business, 1(1), 1-14

12. Nigeria Deposit Insurance Corporation (2005). Annual report and statement of accounts. Abuja: NDIC 
13. Nigeria Deposit Insurance Corporation (2009). Annual report and statement of accounts, Abuja: NDIC

14. Nigeria Deposit Insurance Corporation (2016). Annual report and statement of accounts. Abuja: NDIC

15. Nwokoji, S.H. (2011). Deposit protection and the spread of deposit insurance: Some guidelines for developing countries. Washington: The World Bank.

16. Obienusi, I. \& Obienusi, E.A (2015). Banking reforms and the Nigerian economy: 1990 - 2007. Historical Research Letter, 21(2), 27-31

17. Onaolapo, A. R. (2012) Analysis of credit risk management efficiency in Nigerian commercial banking sector. Far East Journal of Marketing and Management, 7(3), 113-120

18. World Bank Group (2016). Nigeria: Methodological approach for development of target deposit insurance fund model. Technical Report.

\section{Correspondence address:}

Dr. OKEWALE, Joel Adeniyi, Department of Accounting, Olabisi Onabanjo University, PMB 2002, Ago-Iwoye, Nigeria.

Dr. SOYEMI, Kenny Adedapo, Department of Accounting, Olabisi Onabanjo University, PMB 2002, Ago-Iwoye, Nigeria.

MIESEIGHA, Ebipanipre Gabriel, Department of Accounting, Olabisi Onabanjo University, PMB 2002, Ago-Iwoye, Nigeria. e-mail: ebigabriel2007@yahoo.com 